\title{
PENGEMBANGAN MEDIA PEMBELAJARAN AUDIOVISUAL PADA POKOK BAHASAN LAPORAN KEUANGAN PERUSAHAAN JASA
}

\author{
Bisrul Miftachul Asror \\ SMK Negeri Senduro Lumajang \\ bisrulmiftachul@yahoo.com
}

\begin{abstract}
Learning media are used to enhance learning in the classroom. This research applies research and development design. The result of validation by experts judgement obtain the overall average of $73,86 \%$. This suggests that the developed audiovisual media is appropriate to be used in learning accounting. Based on the results of this study it is suggested for the teacher in particular, to make use of audiovisual media in learning process supported by the additional clasroom facilities to optimized its use. New audiovisual media innovation to improve learning might be developed in other learning materials.
\end{abstract}

Keywords: Learning, Media, Audiovisual.

\begin{abstract}
Abstrak: Media pembelajaran digunakan untuk meningkatkan pembelajaran dalam kelas. Jenis penelitian ini merupakan penelitian pengembangan dengan model Dick and Carey. Hasil validasi oleh ahli materi secara keseluruhan diperoleh rata-rata73,86\%. Hal ini menunjukkan media audiovisual yang dikembangkan layak digunakan dalam pembelajaran akuntansi. Berdasarkan hasil penelitian ini disarankan kepada guru khususnya, untuk memanfaatkan media audiovisual dalam proses pembelajaran didukung dengan sarana dan prasarana yang memadai di kelas untuk mengoptimalkan penggunaannya. Inovasi media audiovisual baru untuk meningkatkan pembelajaran dapat dikembangkan pada materi pembelajaran yang lain.
\end{abstract}

Kata Kunci: Learning, Media, Audio Visual.

Guru merupakan salah satu faktor penentu keberhasilan pembelajaran dalam kelas. Peningkatan guru dalam mengelola kelas salah satunya diwujudkan dengan pemanfaatan media pembelajaran. Peran guru pada zaman sekarang bukan sebagai pusat pembelajaran (teacher center). Seiring dengan perubahan paradigma pembelajaran dimana siswa yang harus lebih aktif dalam pembelajaran (student center) maka guru berperan sebagai fasilitator. Sebagai fasilitator, guru harus kreatif dan inovatif dalam memanfaatkan dan menciptakan media pembelajaran. Senada dengan yang diungkapkan Arsyad (2005) bahwa guru dituntut agar 
mampu menggunakan alat-alat yang disediakan oleh sekolah, dan tidak tertutup kemungkinan bahwa alat-alat tersebut sesuai dengan perkembangan dan tuntutan zaman.

Media merupakan alat bantu yang memudahkan seorang guru untuk memberikan pengajaran kepada anak didiknya agar lebih cepat mengetahui, memahami, dan upaya terampil dalam mempelajari bidang studi tertentu, baik media berupa perangkat keras maupun lunak. Media pembelajaran dibuat untuk meningkatkan pembelajaran dalam kelas. Pembelajaran yang dilakukan tanpa variasi akan membuat pelajar akan jenuh dan ilmu yang ditransformasikan oleh guru tidak dapat diserap oleh siswa. Menurut Heinich, Molenda, dan Russel dalam Pribadi (2004: 146-145) pengklasifikasian media pembelajaran mencakup (1) media yang tidak diproyeksikan, (2) media yang diproyeksikan, (3) media audio, (4) media video dan film, (5) komputer, dan (6) multimedia berbasis komputer.

Peranan media dalam proses pembelajaran adalah agar informasi yang disampaikan mudah diterima oleh siswa. Begitu juga dalam mata pelajaran akuntansi. Akuntansi merupakan mata pelajaran yang perlu menggunakan media pembelajaran dalam penyampaiannya. Selain itu dalam pembelajaran juga harus ada materi, metode, media, dan evaluasi. Jika salah satu komponen tidak ada, maka sulit untuk mencapai tujuan pembelajaran. Media pembelajaran yang baik akan membantu proses pembelajaran siswa. Dengan adanya media, proses pembelajaran akan terlihat variatif tanpa mengesampingkan tujuan pembelajaran yaitu mentrasformasikan ilmu kepada siswa agar materi yang diberikan dapat dimengerti dan dipahami. Media dalam pembelajaran pada hakikatnya merupakan cara teratur dan terpikir secara sistematis untuk mencapai suatu tujuan dan memperoleh kemampuan efektifitas belajar yang dilakukan pendidik dan peserta didik.

Materi laporan keuangan merupakan salah satu materi yang dianggap cukup sulit oleh siswa. Kesulitan siswa pada umumnya terlihat ketika siswa memindahkan data dari kertas kerja ke laporan keuangan. Kesulitan lain juga terlihat pada pemahaman siswa pada sistematika laporan keuangan. Berangkat dari permasalahan ini penggunaan media berbasis audiovisual merupakan salah satu alternatif dalam mengatasi permasalahan tersebut. Pengembangan media 
berbasis audiovisual tersebut dalam meteri laporan keuangan diharapkan dapat meningkatkan motivasi dalam mempelajari akuntansi khususnya materi laporan keuangan sehingga materi yang disampaikan dapat diterima dengan baik oleh siswa. Apabila materi yang disampaikan dapat diterima dengan baik diharapkan terjadi peningkatan prestasi siswa sesuai dengan tujuan pembelajaran.

Pengembangan media pembelajaran audiovisual dalam penelitian ini berdasarkan pada teori behavior dimana dalam teori ini digunakan stimulus agar siswa mendapatkan hasil yang baik. Teori behavior berpedoman pada hasil yang dapat diukur dan diamati. Dalam teori ini juga digunakan penguatan untuk mendapatkan tingkah laku yang diinginkan. Hal tersebut sesuai dengan teori (Slavin, 2000) bahwa stimulus merupakan apa yang merangsang terjadinya kegiatan belajar seperti pikiran, perasaan, atau hal-hal lain yang dapat ditangkap melalui alat indera, sedangkan respon adalah reaksi yang dimunculkan peserta didik ketika belajar, yang dapat pula berupa pikiran, perasaan, atau gerakan/tindakan. Dengan demikian perubahan tingkah laku akibat kegiatan belajar dapat berwujud konkrit, yaitu yang dapat diamati, atau tidak konkrit yaitu yang tidak dapat diamati. Aliran behaviorisme sangat mengutamakan pengukuran, tetapi tidak dapat menjelaskan bagaimana cara mengukur tingkah laku yang tidak dapat diamati.

Berdasarkan perkembangan teknologi, Arsyad (2005:29) mengemukakan bahwa media pembelajaran dapat dikelompokkan dalam empat kelompok yaitu: (1) media hasil teknologi cetak, (2) media hasil teknologi audiovisual, (3) media hasil teknologi yang berdasarkan komputer, (4) media hasil gabungan cetak dan komputer. Sudrajat (2008) menambahkan jenis media belajar sebagai berikut: (1) media visual diantaranya: grafik, diagram, chart, bagan, poster, kartun, dan komik, (2) media audial diantaranya: radio, tape, dan laboratorium bahasa, (3) Projected still media diantaranya: slide; over head projektor $(O H P)$, in focus dan sejenisnya, dan (4) Projected motion media diantaranya film, televisi, video (VCD, DVD, VTR), komputer dan sejenisnya. Media audiovisual dapat diartikan sebagai media yang melibatkan indera pendengaran dan penglihatan sekaligus dalam satu proses. 
Media audiovisual digunakan sebagai media yang menyajikan pengalaman yang konkrit melalui visualisasi dengan tujuan antara lain untuk memperkenalkan, memperkaya atau memperjelas konsep yang abstrak dan mendorong timbulnya kegiatan sasaran didik yang lebih lanjut. Dengan adanya visualisasi konsep yang sifatnya abstrak akan menjadi lebih kongkrit Hardjito(2004:91). Hal tersebut senada dengan Juliantra (2010) yng menjabarkan sifat-sifat media audiovisual yang mempunyai kemampuan sebagai berikut: (1) kemampuan untuk meningkatkan persepsi, (2) kemampuan untuk meningkatkan pengertian, (3) kemampuan untuk meningkatkan transfer (pengalihan) belajar, (4) kemampuan untuk memberikan penguatan (reinforcement atau pengetahuan hasil yang dicapai), dan (5) kemampuan untuk meningkatkan retensi (ingatan) media.

Para pendidik dan orang tua tidak dapat mengingkari begitu kuat pengaruh media komunikasi khususnya media audiovisual terhadap anak didik. Daya tarik yang begitu kuat dari media audiovisual bagi anak-anak tidak lepas dari karakteristik media ini yang memiliki beberapa keunggulan dibandingkan dengan media cetak maupun media dengar, sehingga anak-anak sangat menyukainya (Williamhegel, 2009). Hal tersebut diperkuat Pribadi (2004: 154) yang mengungkapkan bahwa media audiovisual banyak digunakan untuk mengajarkan pengalaman belajar yang tidak dapat dilihat secara langsung, hal ini disebabkan media audiovisual memiliki potensi untuk memperlihatkan bagian-bagian dari suatu objek secara realistis.

Pengembangan media audiovisual yang akan dilaksanakan menggunakan software Ulead Video Studio plus 11. Video Studio 11 merupakan salah satu sofware pengolahan video. Meskipun dikhususkan untuk melakukan pengeditan video namun sebenarnya juga mempunyai kemampuan yang handal untuk mengolah suara (sound editing), mengolah teks dan juga mengolah image. Software tersebut merupakan penyempurnaan dari software sebelumnya sehingga diharapkan dapat memperoleh hasil yang baik. Ulead video studio plus 11 sangat bagus digunakan untuk mengedit media audiovisual yang akan dikembangkan. Selain menghasilkan media audiovisual yang baik, Ulead Video Studio plus 11 juga memiliki kesederhanaan antar muka dan kemudahan memahami perintah yang harus dijalankan. Ulead Video Studio 11 memiliki dukungan yang luas pada 
beberapa format video, seperti : format Avi, DV, MPGE atau DVD. Software milik COREL ini dapat mengedit video layaknya video editing profesional dengan mudah. Misalnya membuat adegan video yang terbalik dari rekaman yang ada serta menaikkan playback speed dari video yang dibuat.

\section{METODE}

Pengembangan media pembelajaran audiovisual dilakukan dengan tahapan sebagai berikut: (1) analisis situasi awal, (2) pengembangan rancangan bahan ajar, (3) membuat bahan ajar, (4) tahap penilaian/uji kelayakan, (5) tahap revisi bahan ajar yang menghasilkan produk akhir pengembangan (Dick and Carey, 1990: 9).

Tujuan yang ingin dicapai dari penelitian ini adalah tersusunnya media pembelajaran dengan menggunakan audiovisual yang mampu meningkatkan motivasi siswa dalam materi laporan keuangan. Subyek penelitian ini adalah siswa kelas XI IPS SMA Negeri 3 Blitar. Produk yang dihasilkan berupa media pembelajaran Audiovisual pada materi laporan keuangan perusahaan jasa. Dengan menggunakan Ulead1 11, cool edit, dan frutilup diharapkan media ini dapat menjadi alternatif dalam meningkatkan motivasi belajar serta sebagai sumber belajar bagi para siswa. Produk ini akan dikemas dengan CD (Compact Disk) dengan dukungan perangkat komputer/laptop dan LCD.

\section{HASIL DAN PEMBAHASAN}

Media pembelajaran merupakan segala sesuatu yang dapat digunakan untuk bahan pembelajaran, sehingga dapat merangsang perhatian, minat, pikiran, dan perasaan siswa dalam kegiatan belajar untuk mencapai tujuan belajar. Media audiovisual merupakan salah satu yang menjadi perantara atau alat penyampaian informasi yang mempunyai suara, gambar, gerakan, animasi, dan cahaya.

Media pembelajaran yang dikembangkan merupakan bahan pembelajaran tampak dengar (audiovisual) yang dapat digunakan dalam menyampaikan materi pembelajaran. Dikatakan tampak dengar dimana terdapat unsur dengar (audio) dan tampak (visual) dapat disajikan serentak. Bahan pembelajaran audiovisual sangat penting dikembangkan dalam pembelajaran. Media pembelajaran yang dirancang ini menampilkan media audiovisual seperti animasi gambar, tulisan, 
musik pengiring, narasi,dan dialog yang menjelaskan tentang materi laporan keuangan perusahaan jasa, dimana media audiovisual ini mempunyai karateristik keunggulan dibandingkan media cetak maupun media dengar, sehingga siswa sangat menyukai dan tidak merasa bosan saat proses pembelajaran.

Pengembangan media audiovisual ini menggunakan model pengembangan Dick and Carey (1990), dimana sebelumnya dilakukan observasi dalam menentukan materi yang dipilih dan diangkat dalam media yang akan dikembangkan. Materi yang ditemukan dan layak diangkat dalam media ini adalah laporan keuangan perusahaan jasa dimana siswa mengalami kesulitan dalam memahami komponen laporan keuangan yang berasal dari kertas kerja yang harus dimuat dalam laporan keuangan. Siswa sulit membedakan antara akun riil dan nominal sebagai dasar penyusunan laporan keuangan. Dalam penyusunan sistematika laporan keuangan, siswa masih kurang menguasai sehingga memerlukan media untuk mengatasi masalah tersebut.

Keunggulan media audiovisual sebagai dasar pengembangan media audiovisual pada laporan keuangan perusahaan jasa dimana media audiovisual ini dikemas dengan penyampaian diskusi santai dan ilustrasi soal agar siswa dapat mudah memahami materi. Penyampaian materi disertai diskusi dimaksudkan agar media yang dikembangkan bersifat informatif dan edukatif sehingga dapat meningkatkan pemahaman dan motivasi siswa. Dialog yang disajikan dengan bahasa yang mudah dipahami disertai dengan ilustrasi yang diberikan, dapat memudahkan siswa dalam memahami materi. Hal tersebut senada dengan pendapat Purnama (2009:95) yang menyatakan bahwa media merupakan segala sesuatu yang berfungsi sebagai alat bantu belajar siswa sehingga siswa dapat lebih mudah dalam memahami pelajaran. Hal tersebut juga didukung dengan dialog yang dicantumkan dalam audiovisual yang memuat cerita dan pesan yang berguna baik disampaikan secara tersirat maupun tersurat oleh aktor untuk meningkatkan motivasi siswa.

Spesifikasi media audiovisual yang dikembangkan secara umum terdiri dari: (1) bahan penarik perhatian, (2) tujuan pembelajaran, (3) petunjuk penggunaan media, (4) Materi Pembelajaran, (5) Balikan, dan Ilustrasi soal. Bahan penarik perhatian yang menjadi komponen dari media ini berupa 
visualisasi universitas, kemasan dialog yang interaktif dan memuat cerita tentang kemampuan dan semangat seorang siswa yang diharapkan memberi dorongan bagi peningkatan motivasi belajar siswa khususnya pada materi laporan keuangan. Selain itu, tampilan teks baik font, warna, pemilihan setting musik, ilustrasi dan animasi gambar yang bervariasi juga menjadi penarik dalam media ini. Hal tersebut sejalan dengan pendapat Ramendra dan Ratminingsih (2007:91) yng menyatakan bahwa media audiovisual dapat menjadikan pembelajaran lebih menarik, meningkatkan motivasi dan mempercepat pemahaman siswa terhadap pembelajaran.

Media audiovisual ini dikembangkan dengan menggunakan model pengembangan Dick and Carey (1990), yang telah dimodifikasi untuk menyesuaikan dengan keadaan lapangan, keterbatasan waktu, tenaga dan biaya. Proses pengembangan media audiovisual telah melalui uji validasi ahli materi, ahli media dan uji coba lapangan terbatas (pengguna). Data validasi selain digunakan untuk menguji kevalidan/kelayakan dari media audiovisual juga digunakan sebagai bahan pertimbangan dalam memperbaiki media audiovisual yang dikembangkan. Dari hasil proses validasi, data di analisis dengan menggunakan analisis deskriptif persentase. Berdasarkan data yang diperoleh dari hasil validasi baik dari ahli materi, ahli media dan uji terbatas diperoleh rata-rata sebesar 73,86\%, maka disimpulkan bahwa media audiovisual yang digunakan valid dan dapat digunakan sebagai referensi media dalam pokok bahasan laporan keuangan perusahaan jasa.

Hasil uji validasi yang menyatakan bahwa media audiovisual yang dikembangkan layak digunakan tidak memberi arti dalam tidak dapat meningkatkan hasil pembelajaran siswa. Untuk menguji media audiovisual yang dikembangkan digunakan uji $\mathrm{T}$ (t-test) independent sampel dengan bantuan komputer program SPSS versi 16.0 . Hasil uji T-test pretest diperoleh hasil 0.425 $>0.05$ dengan probabilitas (p) > 0,05. Hal ini mengindikasikan bahwa kemampuan kelas kontrol dan kelas eksperimen mempunyai kemampuan awal yang sama. Sementara hasil t-test posttest dapat diketahui bahwa terdapat perbedaan antara hasil belajar siswa dalam kelas yang diajar dengan menggunakan media pembelajaran berbantuan media audiovisual dengan tanpa 
menggunakan media. Hal ini ditunjukkan dengan adanya angka signifikansi sebesar $0,000<0,05$, dimana jika $(\mathrm{p})<0,05$ hal tersebut menunjukkan bahwa penggunaan media audiovisual pada materi laporan keuangan dapat meningkatkan hasil belajar siswa. Hal tersebut mendukung hasil validasi bahwa media audiovisual yang dikembangkan pada pokok bahsan laporan keuangan perusahaan jasa layak digunakan dan dapat meningkatkan hasil belajar siswa. Berikut pada tabel 1, 2 dan 3 disajikan hasil uji validasi secara kualitatif dari ahli materi, ahli media dan siswa sebagai pengguna.

Tabel 1. Kritik dan saran tentang media audiovisual dari Ahli Materi

\section{Kritik dan Saran}

a) Pemberian warna atau visualisasi pada kertas kertas kerja terutama pada kolom laba rugi dan neraca dibedakan agar dalam pemindahan data dari kertas kerja pada sistematika laporan keuangan lebih mudah dipahami.

b) Penambahan akun laba bersih sebelum pajak, pajak penghasilan, laba bersih setelah pajak pada laporan laba rugi.

c) Penambahan visualisai laporan laba rugi bentuk single step dan multiple step secara bersamaan dan penambahan waktu untuk visualisasi ilustrasi soal..

d) Penambahan keterangan penambahan atupun pengurangan modal pada laporan perubahan ekuitas.

e) Penambahan laporan ekuitas dalam keadaan perusahaan mengalami kerugian dan menampilkan perbedaan dari laporan perubahan ekuitas pada saat rugi dan laba.

f) Penambahan visualisasi neraca bentuk stafel dan skontro secara bersamaan dan penambahan waktu untuk visualisasi ilustrasi soal.

g) Pengurangan materi pada bahasan laporan arus kas dan catatan laporan atas laporan keuangan

Secara umum media audiovisual baik dan dapat digunakan sebagai penunjang dalam

pembelajaran akuntansi khusunya pada pokok bahasan laporan keuangan dan penyempurnaan media yang telah dikembangkang akan membuat media audiovisual yang sempurna dan dapat dimanfaatkan dalam pembelajaran

Tabel 2. Kritik dan Saran tentang media audiovisual dari Ahli Media

\begin{tabular}{|l|}
\hline \multicolumn{1}{|c|}{ Kritik dan Saran } \\
\hline a) Pemilihan musik ilustrasi pada media grafis di ubah, agar menarik perhatian dan \\
enak didengar audience \\
b) Pengambilan teknik pengambilan gambar kurang menerapkan teknik pergerakan \\
kamera Tipografi yang digunakan pada media ini cukup mudah terbaca \\
c) Perlu dirubah beberapa gambar yang kurang pencahayaan atau terlihat gelap \\
d) Dianjurkan pada pengembang untuk mempelajari teknik pencahayaan atau lighting \\
yang \\
e) bagus untuk diluar ruangan. Sebab terdapat hasil video yang gelap. \\
f) Grafis pada media ilustrasi contoh soal kurang inovasi pada komposisi warna \\
g) Penambahan running text berfungsi untuk memperjelas khusus audience yang \\
mengalami gangguan pendengaran (tuna rungu) \\
\hline
\end{tabular}


Menurut pendapat secara umum, media pembelajaran audiovisual yang dikembangkan sudah menggunakan teknik-teknik pembuatan media pembelajaran yang berbasis audiovisual, sehingga media ini layak digunakan dalam proses pembelajaran akuntansi. Media yang dikembangkan akan mempunyai nilai lebih dengan memperhatikan saran atau kritik untuk penyempurnaan media.

Tabel 3. Kritik dan Saran tentang media audiovisual dari Uji Coba Lapangan Terbatas (Siswa)

a) Font dalam ilustrasi soal diperbesar dan kombinasi warna lebih kontras dengan
background agar terlihat jelas
b) Background diberikan warna yang menarik
c) Pencahayaan pada bagian tertentu masih kurang sehingga mengakibatkan visualisasi
d) kurang jelas
e) Pada setiap penjelasan diharapkan ada teks sehingga memudahkan bagi siswa yang
dapat
f) mendengar melalui audio dan teks dialog dari penjelasan dari percakapan.
g) Audio khususnya pada ilustrasi soal sebaiknya diganti dengan lagu yang cocok
dengan
h) media pembelajaran atau lagu yang semangat tidak horor.
i) Durasi waktu penampilan ilustrasi soal di tambah karena terlalu cepat.

Menurut pendapat secara umum, media pembelajaran audiovisual yang dikembangkan sudah baik dan dapat meningkatkan motivasi dan pemahaman siswa . tetapi lebih sempurna apabila kekurangan yang ada diperbaiki sehingga media audiovisual yang dikembangkan dapat dimanfaatkan dalam pembelajaran. Karena media audiovisual dapat memvariasikan pembelajaran di kelas yang dapat menghilangkan kebosanan dalam mempelajari akuntasi khususnya pokok bahsan laporan keuangan.

\section{SIMPULAN}

Berdasarkan hasil validasi oleh ahli materi, ahli media dan pengguna (siswa) secara keseluruhan diperoleh rata-rata73,86\% . Hal ini menunjukkan bahwa media audiovisual yang dikembangkan layak digunakan dalam pembelajaran akuntansi. Hasil tersebut juga didukung rata-rata nilai kelas eksperimen lebih besar dari pada kelas kontrol, yakni 90.17 kelas eksperimen dan 82.40 kelas kontrol. Hasil analisis uji T-test independent sample diperoleh nilai 0,000 lebih kecil daripada 0,05. Berdasarkan hasil validasi dan uji T-test independent sample bahwa media audiovisual yang dikembangkan layak digunakan dan dapat meningkatkan hasil belajar siswa.

Berdasarkan hasil penelitian ini disarankan kepada guru khususnya,untuk memanfaatkan media audiovisual dalam proses pembelajaran. Sarana dan 
prasarana di kelas hendaknya memadai untuk menunjang proses pemanfaatan media secara optimal. Lebih jauh diharapkan agar dapat dikembangkan media audiovisual pada materi lain untuk meningkatkan kualitas pembelajaran.

\section{DAFTAR RUJUKAN}

Arsyad, Azhar. 2005. Media Pembelajaran. Jakarta: PT Grafindo Persada

Dick, W., Carey, L. 1990. The Systematic Design of Instruction. United States Of America: Foresman and Company

Hardjito. 2004. Peran Guru Dalam Pemanfaatan Media Pembelajaran Ditinjau Dari Prespektif Progrsif. Teknodik:7(14):85-107

Pribadi, Benny A. 2004. Ketersediaan Dan Pemanfaatan Media Dan Teknologi Pembelajaran Di Perguruan Tinggi. Jurnal Pendidikan, 5(2):145-156.

Purnama, S Edy. 2009. Optimalisasi Prestasi Belajar Matematika Melalui Pembelajaran Dengan Media CD Interaktif ( Multimedia) Bagi Siswa Kelas 7-C SMP Negeri 1 Sruweng Kabupaten Kebumen. Jurnal Pendidikan, 5(1):92-99

Ramedra, Dewa Putu dan Ratminingsih, Ni Made. 2007. Pemanfaatan Audiovisual Aids dalam Proses Belajar Mengajar Mata Pelajaran Bahasa Inggris di Sekolah Dasar. Jurnal Penelitian Dan Pengembangan Pendidikan:1(2):7895

Sudrajat, A. 2008. Belajar Media Pembelajaran. (Online) (http://www.google.com/ Media Pembelajaran.html diakses 4 maret 2011

Williamhegel. 2009. Belajar Media Audiovisual. (Online) ( http:// www.william hegel's. Blog/Belajar Dengan Media Audiovisual. html diakses 4 maret 2011) 